At the third reading in the House of Lords on May 27, Lord Salisbury, in reply to questions from Lord Stansgate and Lord Jowitt, explained that the Estimate to be submitted to Parliament in accordance with Clause 4 of the Bill would be in two parts. The first part would cover the expenses of the small office which will assist the Lord President to discharge his atomic energy function. The second, covering some 99 per cent or more of the total, would represent the money which the Lord President would pay over to the Authority. It would be broken down under a number of headings, though the information would be rather less detailed than is usual in regard to an ordinary departmental Vote, having regard both to the need for security and to creation of a body with freedom to run its own day-to-day affairs. The exact form of presentation, said Lord Salisbury, is still being discussed, but the breakdown will not permit a distinction to be drawn between expenditure for civil purposes and expenditure for defence. For security reasons, moreover, sums included in the Ministry of Supply and Service Department Votes for payments to the Authority for work on atomic weapons will not be shown separately, but the degree of parliamentary control provided under the clause is substantially greater than has existed in the past. Referring to the importance of a proper balance of the use of atomic energy between military and civil purposes, Lord Salisbury said that this is a major reason for transfer of responsibility from the Minister of Supply to the Authority. At present none of the energy which will be created will be allocated to private industry ; it will all be in the hands of tho British Electricity Authority, which ultimately will transmit the electrical power to industry.

\section{Queen Elizabeth House : a New Centre in Oxford for Colonial Studies}

A NEW centre for Colonial studies is to be established in Oxford under the joint auspices of the Colonial Office and the University, and H.M. the Queen has been graciously pleased to allow it to be named Queen Elizabeth House. For some time past it has been obvious that the cultural, economic and social life of the overseas territories of the British Commonwealth for which the United Kingdom Government is responsible has been changing very rapidly, and it is imperative that relationships between the people of these territories and those of the United Kingdom (and of the Commonwealth generally) be adjusted in harmony with these changing conditions. Much has already been done by university studies and cultural contacts promoted by government and other bodies; but what has hitherto been lacking is some recognized centre, associated with the many bodies and institutions at work in this field, but not designed to supplant or interfere with their various activities. To this centre students and visitors from overseas, together with persons in Britain concerned with the problems facing the oversea territories, could come for free discussions with others who share their interests and be put in touch with those who can help them in their studies. Such a centre, in addition to the services which it could render to individuals, could provide a setting for conferences and summer schools as well as for more formal courses arranged by government or other authorities for men and women working, or intending to work, overseas. To perform these funetions effectively, the centre would have to be residential and located in suitable academic surroundings.
Recently, Sir Ernest Oppenheimer offered $£ 100,000$ to the University of Oxford for the development of Colonial and allied studies, on the understanding that a centre of the kind described above would be established in close connexion with the Institute of Colonial Studies already existing in Oxford, though not exclusively linked to it in such a way as would prevent the fullest co-operation with other interested bodies. In recognition of the important part which such a centre could play in the training of Colonial Civil servants and other cognate activities, the British Government has promised a contribution towards building costs of up to $£ 50,000$ from Colorial Development and Welfare Funds. The University of Oxford is now co-operating in securing a suitable site and in establishing the centre upon it. In order thet the centre may be brought into being as soon as possible, arrangements are being made for constituting a governing body on which official, academic and other interests will be represented.

\section{New Nature Reserves in Britain}

Two further nature reserves were declared on June 15 by the Nature Conservancy. The first of these consists of the Huntspill River and Huntspill sea-wall area of about 300 acres and roughly 6,000 acres of tidal mud flats near the mouth of the River Parrett in Bridgwater Bay. Steart Island will be added by a further declaration on the expiry of the existing tenancy over it next year. The mud flats are the scene of a most successful experiment in harnessing vegetation to the work of coastal defence : the introduction of Spartina townsendii considerably raised the foreshore-level and gave effective protection against incursions by high tides. Further experiments are planned by the Conservancy in collaboration with the Somerset River Board. The flats are also of great ornithological interest as a roosting place for wildfowl, including wild geese, and for waders, forming the only gathering ground for moulting shelducks in Great Britain. The discontinuance of existing shooting rights will provide a large sanctuary area in which wildfowl and waders can feed and roost undisturbed and build up stocks of these species.

The second new reserve, Castor Hanglands, is in the parishes of Ailsworth and Marholm, four miles west of Peterborough. It consists of $12 \frac{1}{2}$ a.cres of mixed woodland, known as the Blacklands, and about 93 acres of rough grassland and bushes called Ailsworth Heath, which was originally recommended as a nature reserve in 1947, particularly for the rich insect life and wide range of plant life to which the soils derived from oolitic limestones and calcareous clays give rise and of which few examples remain. There are two small pools in the reserve which support a variety of aquatic vegetation, and the heaths and woodlands harbour the rare butterflies, the black hairstreak (Strymon pruni), tho large tortoiseshell (Nymphalis polychloros) and the chequered skipper (Carterocephalus pakeman). Access to Blacklands will be by permit; but there will be no restriction on public access to Ailsworth Heath, though permits to collect will be required.

\section{Ethnology of Saipan in the Mariana Islands}

IN Vol. 14 (anthropology) of Fieldiana (pp. 384 ; Chicago Natural History Museum, 1954; 5 dollars), Alexander Spoehr discusses Saipan in the Mariana Islands, and describes Spanish, German, Japanese and recent American rule in those islands. Tho 